\section{Finances a Focus for 2002}

Tony Naldrett, GSA President

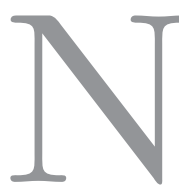

ow that I have been your president for about three months, the magnitude of the job that I have taken on is slowly dawning on me.

Nevertheless, I feel extremely honored by the confidence that you have placed in me and promise you that I will do everything I can to do the job properly. Of course, while he/she has most of the responsibility, the president only assumes a little of the work. In this respect, I am very fortunate that my taking over the presidency coincided with some very important new arrivals, above all that of Jack Hess as executive director.

Jack comes to GSA with a wide experience in geoscience management with the Desert Research Institute in Nevada and from two years working the political scene on Capitol Hill. He has already given me the benefit of his experience and led me to revise some of my decisions, for which I'm extremely grateful. I am also fortunate in having John Costa, who is proving to be a determined and resourceful treasurer, Clark Burchfiel, who is already contributing as vice-president, and four new councilors, Judith Parrish, Ron Clowes, David Fountain, and Richard Gray, who cover a wide range of disciplines and whose advice, along with that of councilors already in office, will be much appreciated.

I can't conclude this introductory stage of my message without saying how much I will be relying on the advice of past president Sharon Mosher. Sharon enjoyed (I hope this is the right word!) nine years of continuous service with GSA (four years on council, four years service with the Annual Program Committee, and one year as vicepresident) before she took over as president. During this time, she not only revamped the GSA annual meeting technical program to make it much more interesting and in tune with the times, but she acquired an intimate knowledge of the workings of GSA at all levels-Council, committees, and headquarters - that made her uniquely equipped to cope with the problems that arose during her presidency and to establish procedures for dealing with problems during future presidencies. She made the year of her presidency a full-time job, which she crammed into the spare time that the University of Texas allowed her. Every single member of GSA owes her (and, I suspect, U. of T.) a debt of gratitude that can never be repaid.
At this stage, there seems little doubt that the greatest problem GSA will be facing over the next few years will be that of finance. Perhaps some of you are not aware that your membership dues entitle you to benefits that go far beyond what those dues can support. The remainder either comes from revenue-generating activities, such as publications, meetings, and grants, or from judicious cultivation of the investment portfolios of the Society and of the GSA Foundation. All institutions fortunate from their investment portfolio and as a working rule typically spend less than 5 percent of the total portfolio each year. Experience has shown that if expenditures do not rise above 5 percent, given the overall growth in capital markets, the value of a portfolio will increase in the long run at a rate that is above that of inflation. Of course, there are bad periods, such as the one that we are going through now, but growth during good periods more than offsets the downturns and enables a steady revenue to be enjoyed each year without punishing the portfolio unduly.

The problem is that since 1988, GSA (I'm referring to the Society, not the Foundation) has been spending more than 7 percent each year. This has been done in the support of very good causes and in response to the wishes of the membership. Examples of important initiatives GSA has helped support during this period include the Decade of North American Geology volumes, outreach programs, and the GSA research grants program.

The result of the enthusiastic support of initiatives like these has been that the portfolio has not grown sufficiently to be well insulated from downturns in the market. The period from 1992 to 2000 is a particularly clear example; market growth was so strong and constant that the portfolio continued to grow in a pleasing manner despite overspending. In contrast, the decrease in the market over the last two years, particularly during 2001, leaves us in a very difficult position. We have cut expenditures to the bone, but we have a wonderful series of programs, a magnificent headquarters staff to administer them, and a profile within the earth science community that no one wants to see diminished.

This then is the challenge that we-me, as your president; John, as your treasurer; your Council; and above all, Jack Hessenough to have investments obtain revenue
DIALOGUE

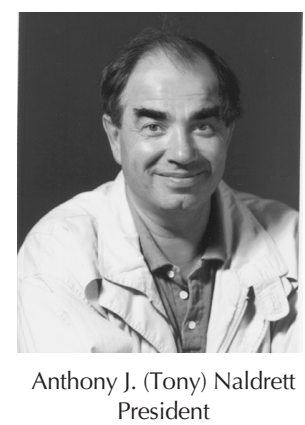

have to face. Under Sharon's guidance, last year's Council approved procedural changes in budgeting and financial control that should bring things under control in time. Essentially, Council required that over the next 12 years, there will be a progressive decrease of 0.5 percent each year in GSA's reliance on its investment income for the operational budget. This will be accomplished by effecting economies in our present operations and emphasizing the revenue-generating potential of our programs and projects. Twelve years from now, no operating income should be derived from the portfolio, which will then be used to fund important new initiatives. It is an unfortunate fact that spending limits mandated by previous Councils were not fully enforced. During the next few years, things MUST be different. We MUST bring our budget into line. We MUST stop the erosion of our investment portfolio.

I wish that my first message to you could be a more positive one- that I could have emphasized new programs and projects or positive modifications to old programs and projects. Many such aspects are on stream and others I will tell you about in future messages, but all are constrained by our need to reduce expenses and raise revenue, and I felt it essential to let you know now where we stand.

During this time, we look to you for understanding and for support, particularly in the areas of education, outreach, and public policy. Your support can take many forms, and I would refer you in particular to Sharon Mosher's Presidential Address that also appears in this issue. Clearly, until new revenue-generating activities have developed their full potential, we will have a tough time over the short term in continuing to provide you with the services that have been paid for in the past largely out of investment income. Be assured that all of us on Council and at headquarters will be working to the utmost of our abilities to resolve these issues. 